\title{
Carbon Capture Test Unit Design and Development Using Amine- Based Solid Sorbent
}

\author{
Ronald W. Breault ${ }^{* 1}$, James L. Spenik ${ }^{2}$, Lawrence J. Shadle ${ }^{1}$, \\ James S. Hoffman ${ }^{3}$, McMahan L. Gray ${ }^{3}$, Rupen Panday ${ }^{2}$ and Richard C. Stehle ${ }^{4}$ \\ ${ }^{1}$ NETL US Dept. of Energy, \\ 3610 Collins Ferry Rd., \\ Morgantown, WV \\ ${ }^{2}$ REM Engineering Services, \\ 3610 Collins Ferry Rd., \\ Morgantown WV \\ ${ }^{3}$ NETL US Dept. of Energy, \\ 626 Cochrans Mill Road \\ Pittsburgh, PA \\ ${ }^{4}$ ORISE \\ 3610 Collins Ferry Rd., \\ Morgantown, WV
}

* Corresponding author, ronald.breault@netl.doe.gov; 304-285-4486;

US DOE/NETL, PO Box 880, Morgantown, WV 26507 


\begin{abstract}
:
This paper presents the design and development of a reactor system and the subsequent modifications to evaluate an integrated process to scrub carbon dioxide $\left(\mathrm{CO}_{2}\right)$ from synthetic flue gas using amine based solid sorbents. The paper presents the initial system design and then discusses the various changes implemented to address the change in sorbent from a $180 \mu \mathrm{m}$ Geldart group B material to a $115 \mu \mathrm{m}$ Geldart Group A material as well as issues discovered during experimental trials where the major obstacle in system operation was the ability to maintain a constant circulation of a solid sorbent stemming from this change in sorbent material.

The system primarily consisted of four fluid beds, through which an amine impregnated solid sorbent was circulated and adsorption, pre-heat, regeneration, and cooling processes occurred. Instrumentation was assembled to characterize thermal, hydrodynamic, and gas adsorption performance in this integrated unit. A series of shakedown tests were performed and the configuration altered to meet the needs of the sorbent performance and achieve desired target capture efficiencies. Methods were identified, tested, and applied to continuously monitor critical operating parameters including solids circulation rate, adsorbed and desorbed $\mathrm{CO}_{2}$, solids inventories, and pressures.
\end{abstract}

Keywords: $\mathrm{CO}_{2}$ adsorption, Carbon capture, Fluidization, Moving bed, Regenerator

\title{
1. Introduction
}

The United States emits more $\mathrm{CO}_{2}$ than any other country, except China, with nearly $40 \%$ from fossil fuel-fired power plants (U.S. DOE, 2012). Successful carbon management relies on the development of cost effective methods to capture $\mathrm{CO}_{2}$ from the flue gas of existing power plants (Ciferno, 2008; Pires et al, 2011; Susarla et al, 2015). Baseline studies for adding $\mathrm{CO}_{2}$ capture and sequestration to existing power plants indicate that, using conventional technology, the cost of electricity would nearly double from coal fired pulverized coal power plants (Black, 2010). $\mathrm{CO}_{2}$ capture can be realized in a two-step sequestration process where $\mathrm{CO}_{2}$ is first separated from product gases and then stored in geological locations within the earth. Chemical solvent based absorption systems have been utilized and studied for nearly a century and have not shown the ability to limit significant cost or loss in efficiency below target values (Burchell et al, 1997; Yong et al, 2002).

Chemical adsorption using solid sorbents has been widely investigated and considered to be a promising alternative to liquid solvents for $\mathrm{CO}_{2}$ capture. The use of light weight and selective solid sorbents coated with polyamines offer potential cost savings over conventional liquid based systems (Fisher and Keller, 2011; Yang and Hoffman, 2009). Solid sorbents have the potential to be used over a wide range of 
temperatures up to $700^{\circ} \mathrm{C}$ and have been shown to be less environmentally impactful, when compared to liquid adsorbents. The use of solid sorbents has the potential to reduce process costs as compared to conventional liquid based systems by reducing evaporative heat losses (Frimpong et al, 2013; Zhenissova et al, 2014). Solid sorbents with high $\mathrm{CO}_{2}$ capacity and readily adsorb and release $\mathrm{CO}_{2}$ can improve the cost competitiveness of these processes.

Amine sorbents have a high capacity for $\mathrm{CO}_{2}$, can be hydrophobic, and can readily adsorb and release $\mathrm{CO}_{2}$ (Gray et al, 2008; Gray et al, 2003; Gray et al, 2005; Gray et al, 2004; Heydari-Gorji et al, 2011; Monazam et al, 2012; Samanta et al, 2012; Siriwardane, 2005). These sorbents adsorb $\mathrm{CO}_{2}$ at low temperatures and release it at elevated temperatures. Scale up to utility applications requires that the solids are transported or conveyed between the adsorber and the regenerator. Fluidized bed technology appeared to be well suited for this type of thermal swing process because gas-solids suspensions can be readily transported between different reactors. Unfortunately, recent attempts to demonstrate integrated adsorption and regeneration were unable to achieve significant $\mathrm{CO}_{2}$ capture during continuous flow process with an amine based sorbents. Sjostroma et. al. (2012) identified multiple potential causes such as deficiencies in sorbent and operating conditions. Long term stable operation and continuous solids circulation between two fluidized beds has been reported to demonstrate a system design that allows for high $\mathrm{CO} 2$ capture efficiency but is still limited to an efficiency lower than $90 \%$. Factors affecting the working capacity of the sorbents, which limits the capture efficiency, are mainly due to high adsorption temperatures and short absorber residence times (Zhao et al, 2013). Recently, a system study done by Proll et. al. (2016) with a double loop fluidized bed, showed reduction in sorbent circulation rates resulting in lower energy demand for the capture process. The study showed the potential of high carbon capture rates as well as low overall heat requirements through a temperature or thermal swing process. Temperature swing adsorption technology has previously shown reduction in thermal energy requirement while maintaining continuous $\mathrm{CO} 2$ capture in circulating fluidized bed systems and bubbling fluidized beds. (Veneman et al, 2012; Zhang et al, 2014).

A small scale system was designed and constructed to evaluate various solid sorbents operated in a circulating fluid bed system using a thermal swing process. The original design incorporated the hydrodynamic characteristics of a certain class of particles; however, the sorbent that was ultimately available deviated from these. Other factors were also discovered that required modification of the system. The evolution of the experimental system is traced from concept through shakedown to final configuration. The design basis is described and causes for major modifications identified. Critical process measurement and control systems were developed to improve process stability and provide realtime measurement of process performance. 
Sjostroma et. al. (2012) demonstrated that $\mathrm{CO}_{2}$ adsorption occurs within a short section (less than $0.7 \mathrm{~m}$ ) in the entrance of the riser. Ryan et al, (2013) and Breault and Huckaby (2013) present CFD simulations showing the $\mathrm{CO} 2$ removal all taking place within the $0.7 \mathrm{~m}$ riser entrance region. As a result, the focus of this research was to further elucidate regeneration of the sorbent in a closed loop system since adsorption had been experimentally demonstrated.

\section{Unit Design and Development}

A small scale circulating fluidized bed system (Carbon Capture Unit or C2U) was designed to test the effectiveness of solid amine based sorbents for use in the capture of $\mathrm{CO}_{2}$ from flue gas. The original $\mathrm{C} 2 \mathrm{U}$ design can been seen in Figure 1 below where each component is identified along with fluidization gas inlet locations marked numerically. The C2U consisted of four fluidized bed vessels: the adsorber, the regenerator, plus the upper and lower loop seals. Nitrogen was supplied at all fluidization locations and would act as a synthetic flue gas. Note that in a commercial unit, steam will replace the $\mathrm{N}_{2}$ used in this test units for fluidization of the regenerator. The regenerator product gas will then consist of steam and $\mathrm{CO}_{2}$, the steam will be condensed and the remaining high purity $\mathrm{CO}_{2}$ would then be compressed to be utilized or sequestered. Nitrogen and $\mathrm{CO}_{2}$ were introduced to the adsorber plenum (1) and passed through a distributor plate into a fluidized bed of $\mathrm{CO}_{2}$ free sorbent where $\mathrm{CO}_{2}$ was captured from the flue gas in an exothermic process. A reduction in pipe diameter at the adsorber top increased exiting gas velocity and acted as a riser transporting the $\mathrm{CO}_{2}$ laden sorbent. Within the adsorber, the sorbent captured $\mathrm{CO}_{2}$ as particles migrated upward toward the riser inlet. Sorbent particles, with adsorbed $\mathrm{CO}_{2}$, and flue gas with reduced $\mathrm{CO}_{2}$ concentration, were subsequently transported via the riser to the crossover. Particles and remaining flue gas passed through a crossover and into a cyclone where solids and gas were separated. Solid particles exited the cyclone bottom and the remaining flue gas exited the cyclone top and was vented to atmosphere. $\mathrm{CO}_{2}$ carrying sorbent filled the cyclone dip-leg. Aeration $\left(\mathrm{N}_{2}\right)$ near the base of the cyclone dip-leg (8) was used to move sorbent into the upper loopseal that was fluidized with $\mathrm{N}_{2}$ (7). Particles then moved through the loopseal, overflowing into the regenerator.

Within the fluidized regenerator (6), solids at the regenerator top gradually moved downward as particles at the bottom were removed through the underflow. During this process, the sorbent was heated by contact with internal coils through which heated oil was circulated, releasing captured $\mathrm{CO}_{2}$ in an endothermic reaction. The $\mathrm{CO}_{2}$, now in concentrated form, exited the regenerator. Particles were drained from the bottom of the regenerator at the same rate they entered the top. As the moving bed of $\mathrm{CO}_{2}$ stripped sorbent reached the bottom of the regenerator it passed into the standpipe. The standpipe was aerated with stripping gas (5) and move air (4). At the L-valve, particles were transported through a horizontal pipe section fluidized with sparger gas (3) and eventually arrived at a second loopseal. As with 
the upper loopseal, sorbent was fed into the bottom and migrated upward to the top. Sorbent fell from the top of the lower loopseal (2) to the bottom of the adsorber, completing the sorbent circulation loop.

Streams 2-4 enter the adsorber as well.

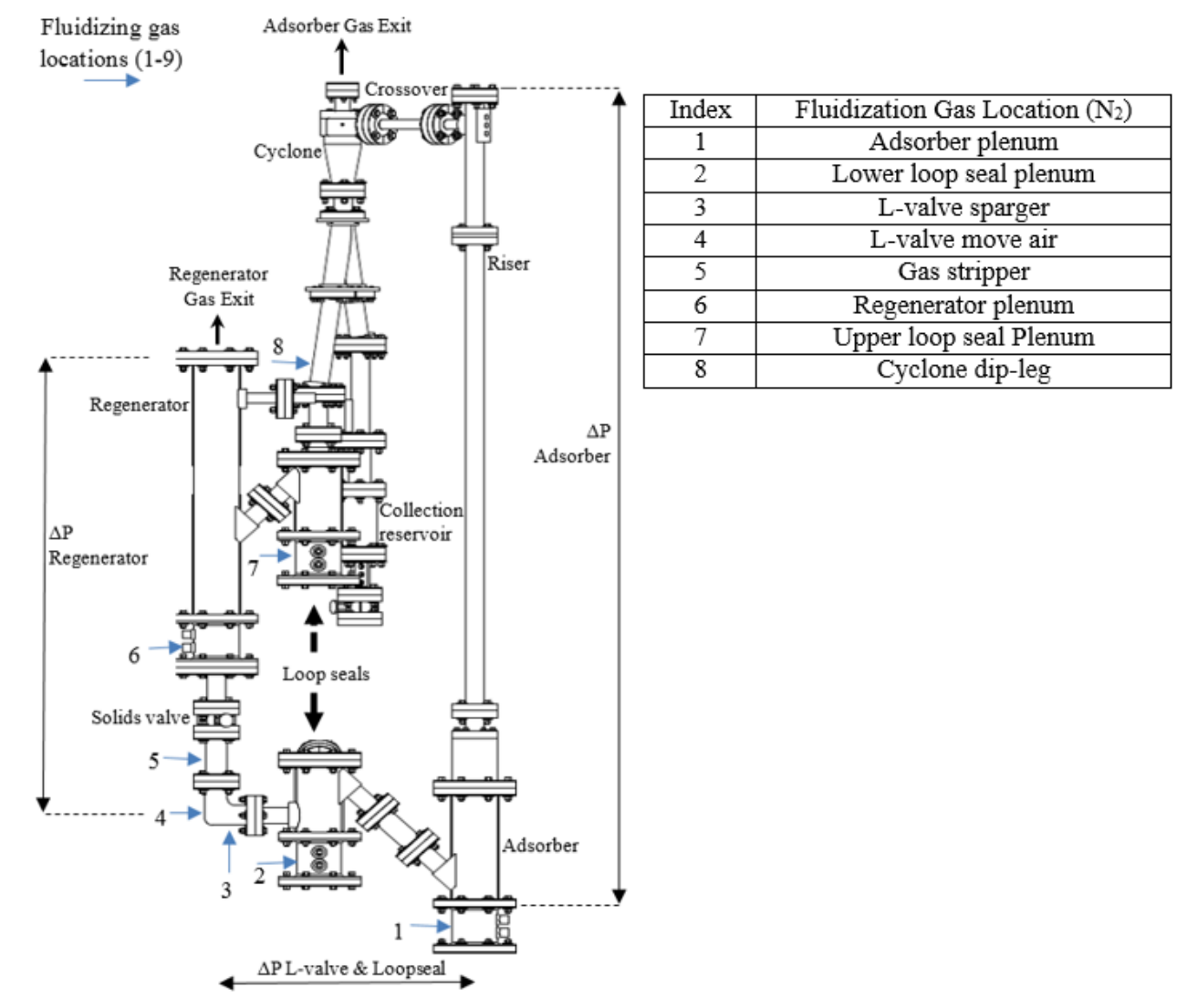

\section{Figure 1 Schematic of primary components of the C2U (Mod-0 geometric configuration) along with fluidizing gas inlet locations.}

Alterations were made to the system to improve operability and solids transport as experiments progress (Figure 2). Glass beads were successfully circulated in the original geometric design (Mod 0), however, lighter sorbent would not successfully circulate. The lower loopseal was dropped to the adsorber level and the $90^{\circ} \mathrm{L}$-valve was replaced with a sweeping arc (Mod 1). Additionally, the cyclone dip-leg was shortened, effectively increasing the overall height between the bottom of the regenerator and the bottom of the lower loopseal. There was continuing difficulty in maintaining consistent solids circulation rates so the L-valve was reintroduced, this time with a sparger to fluidize the horizontal section of the L-valve (Mod 2). A third modification entailed replacing the $5 \mathrm{~cm}$ ID riser with a $2.5 \mathrm{~cm}$ pipe and later heating coils were placed in the upper loopseal to preheat sorbent entering the regenerator (Mod 3-4). The final modification extended the regenerator approximately $0.3 \mathrm{~m}$ (Mod 5). A detailed explanation of each modification and its effects are provided later. 


\begin{tabular}{|c|c|}
\hline Modification Step5 & Alterations \\
\hline 1 & Lowered the lower loop seal and shortened dip-leg. L-valve replaced with swinging arc. \\
\hline 2 & L-valve reinstalled with sparger. \\
\hline $3-4$ & $5 \mathrm{~cm}$ riser reduced to $2.5 \mathrm{~cm}$. Heating coils replaced in upper loop seal. \\
\hline 5 & Regenerator lengthened $0.3 \mathrm{~m}$ \\
\hline
\end{tabular}

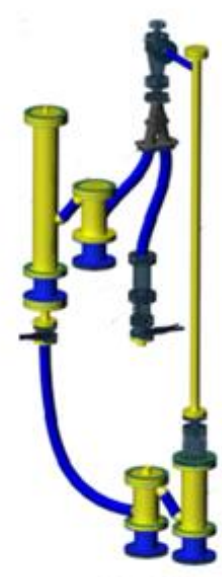

Mod 1

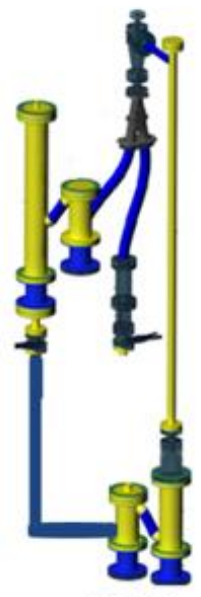

Mod 2

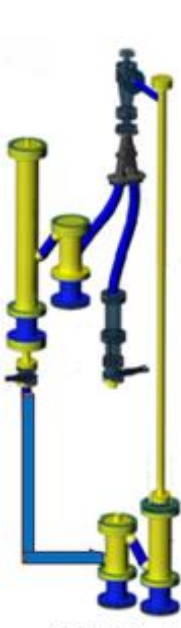

Mod $3-4$

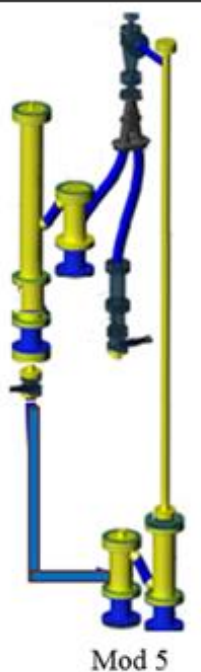

Figure 2 Evolution of C2U system through modification steps.

Figure 3 illustrates a typical pressure profile during operation across the system circulating AX sorbent. Pressure relative to atmosphere was measured at the L-valve on the regenerator side and in the plenum on the adsorber side. Incremental pressures were measured between the L-valve and solids valve (a), solids valve to regenerator bottom (b), regenerator solids region (c) and regenerator freeboard (d) on the regenerator side. On the adsorber side, incremental pressures across the distributor plate (e), adsorber bed (f), transition (g), riser (h), crossover (i) and filter (j).

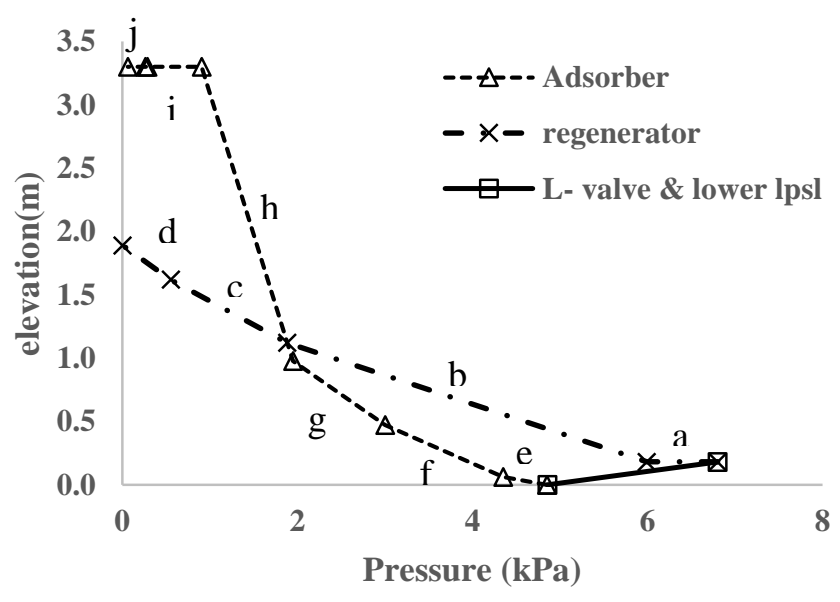

Figure 3 Typical pressure drops across system components (Mod 4) 


\subsection{Original System Design}

The design of the $\mathrm{C} 2 \mathrm{U}$ system was subject to a number of constraints and design parameters which are listed in Table 1. The footprint of the $\mathrm{C} 2 \mathrm{U}$ system was of primary concern during the initial design phase. The overall height of the system needed to be less than $3.7 \mathrm{~m}$ due to the anticipated location of the apparatus. Likewise, the diameter of the vessels could not exceed about $0.152 \mathrm{~m}$ due to the availability of $\mathrm{CO}_{2}$. The $\mathrm{CO}_{2}$ was to be provided by pressurized cylinders, thus a reasonable volumetric flow rate was required. Since the purpose of the system was to analyze various types of solid sorbent and a particular sorbent was unavailable at the time, the system was designed based on a proxy sorbent. The substrate was based on the characteristics of a glass beads (density $=2.5 \mathrm{~g} / \mathrm{cc}$, particle diameter $=180 \mu \mathrm{m}, \mathrm{U}_{\mathrm{mf}}=2.7$ $\mathrm{cm} / \mathrm{s}$ ) with an assumed working capacity of $1.5 \mathrm{gmol} \mathrm{CO}_{2} / \mathrm{kg}$ sorbent.

Table 1 Design Basis for C2U

\begin{tabular}{l|cc}
\multicolumn{1}{c}{ PARAMETER } & UNITS & VALUE/CONSTRAINT \\
\hline MAXIMUM HEIGHT & $\mathrm{m}$ & 3.7 \\
CO2 AVAILABILITY & $\mathrm{slpm}$ & 24.2 \\
CO2 IN FEED & $\mathrm{Vol} \%$ & 15 \\
VOLUMETRIC FLOW & $\mathrm{slpm}$ & 161 \\
RISER DIAMETER & $\mathrm{m}$ & 0.152 \\
\hline PARTICLE INFORMATION & & 180 \\
\hline DIAMETER & $\mu \mathrm{m}$ & 2500 \\
DENSITY & $\mathrm{kg} / \mathrm{m}^{3}$ & 0.027 \\
UMF & $\mathrm{m} / \mathrm{s}$ & $\mathrm{B}$ \\
GELDART & - & 1.5 \\
CLASSIFICATION & $\mathrm{gmol} \mathrm{CO} / \mathrm{kg}$ & 42 \\
WORKING CAPACITY & $\mathrm{kg} / \mathrm{hr}^{2}$ & 1.51 \\
SORBENT FLOW RATE & $\mathrm{kW}$ & \\
EXOTHERMIC HEAT & & \\
GENERATION & &
\end{tabular}

This material should behave as a Geldart group B material. A flow rate producing a superficial gas velocity of $6.5 \times \mathrm{U}_{\mathrm{mf}}$ was envisioned as a moderate case for adsorber inlet flow. Vessel diameters, using the original polycarbonate were $0.14 \mathrm{~m}$, yielding an internal floor area of $0.0154 \mathrm{~m}^{2}$ (disregarding the 
presence of internal coils). Therefore, the adsorber baseline total volumetric flow was $161 \mathrm{slpm}$ of simulated flue gas with a $15 \%$ volume concentration of $\mathrm{CO}_{2}$. The sorbent was required to adsorb 24.2 slpm $\mathrm{CO}_{2}(0.91 \mathrm{gmol} / \mathrm{min}, 0.67 \mathrm{~g} / \mathrm{s})$ setting the solids circulation rate at $0.72 \mathrm{~kg} / \mathrm{min}$. As a baseline for initial calculations, the heat of reaction of MEA sorbent (1.91 x10 $\mathrm{J} / \mathrm{kg} \mathrm{CO}_{2}$ adsorbed) (Amines and Plasticizers, 2004) was used so the heat produced by the exothermic adsorption would be $1.51 \mathrm{~kW}$. This heat is to be removed via internal cooling coils if a constant bed temperature is to be maintained. The characteristics of the coils will be addressed in a succeeding section.

Terminal velocity of an individual glass sphere was determined to be about $1.1 \mathrm{~m} / \mathrm{s}$. Terminal velocity was calculated in its simplest form assuming monodisperse distribution of spherical particles where drag equals weight, $A_{p p}$ is the projected area of the sphere and $C_{D}=24 / \operatorname{Re}_{p} *\left(1+0.1935 * \operatorname{Re}_{p}{ }^{0.6305}\right)$ and $\operatorname{Re}_{p}=$ $\rho_{\text {gas }} V_{\text {term }} d_{\mathrm{p}} / \mu_{\text {gas }}$ (Yang, 2003).

$$
V_{\text {term }}=\sqrt{\frac{2 W}{C_{D^{*} \rho_{g a s} * A_{p p}}}}
$$

More accurate methods of terminal velocity calculation are available, however the solids are not expected to be completely spherical or monodisperse, nor will only a single particle be involved. However, only a general indication of an adequate riser diameter is required so the method employed will serve its purpose. The pipe diameter of the riser section was originally chosen to be $5.1 \mathrm{~cm}$. The volumetric flue gas flow through the riser has been reduced to $137 \mathrm{slpm}$, in the base case, since the $\mathrm{CO}_{2}$ component was adsorbed. Therefore, riser gas velocity is $1.13 \mathrm{~m} / \mathrm{s}$ which exceed the terminal velocity making particle transport possible.

$\mathrm{CO}_{2}$ laden particles along with the $\mathrm{CO}_{2}$ reduced flue gas, transported up the riser, now proceed into the cyclone for separation. The flue gas exits the cyclone vortex finder then through an external filter and finally to the atmosphere. Solids fall from the cyclone down comer into the bottom of the upper loopseal. The upper loopseal, with a diameter identical to that of the adsorber, is fluidized near the minimum fluidization velocity with approximately $25 \mathrm{slpm} \mathrm{N}$. Eventually, the $\mathrm{CO}_{2}$ laden sorbent particles migrate to the regenerator where $\mathrm{CO}_{2}$ is to be desorbed. The regenerator is also fluidized with $\mathrm{N}_{2}$, now at approximately twice $\mathrm{U}_{\mathrm{mf}}(50 \mathrm{slpm})$. Within the regenerator it is necessary to add the approximately 1.5 $\mathrm{kW}$ of energy liberated in the adsorber to the regeneration process. Additional sensible energy must also be added to increase the sorbent to the regeneration temperature. A specific heat of $1000 \mathrm{~J} / \mathrm{kg}-\mathrm{K}$ was assumed for the proxy sorbent, initial temperature of $70^{\circ} \mathrm{C}$ and final temperature of $110^{\circ} \mathrm{C}$. The circulation rate was previously determined to be $0.72 \mathrm{~kg} / \mathrm{min}$, and sensible heat required is $0.48 \mathrm{~kW}$. Total heat required is $2.0 \mathrm{~kW}$ supplied by internal coils with heated circulating oil for testing purposes A 
real world application would likely utilize superheated steam for fluidization rather than the $\mathrm{N}_{2}$ used in the test unit. The steam will have the added benefit that it can supply the heat addition rather than internal coils. The use of steam will improve the product $\mathrm{CO}_{2}$ as it will not be diluted with $\mathrm{N}_{2}$. Steam requirements have been estimated previously for various reactor configurations and represented less than $50 \%$ of the steam requirements and approximately $1 / 3$ of the power loss as compared to a conventional MEA carbon capture system (Hoffman et. al. 2008).

\subsection{Instrumentation}

The $\mathrm{C} 2 \mathrm{U}$ facility consisted of regular process instruments for measuring gas flow rate, pressure, temperature, heat flux and weight of solids. Other instrumentation was used to measure relative humidity and $\mathrm{CO}_{2}$ concentration; control heating of the granular beds (regenerator and upper loopseal) and cooling in the (adsorber and/or lower loopseal) and protected the unit from high pressure or high temperature excursions.

Plenum, sparger, motive, dilution and standpipe fluidization gas flows were metered with Alicat mass flow controllers. Standard conditions were taken as $25^{\circ} \mathrm{C}$ and 1 atmosphere as per Alicat mass flow controller specifications.

Thirteen Alicat mass flow controllers with flow ranges from 0-20 up to 0-500 slpm and preprogrammed for gas composition were used. Process gases used in the $\mathrm{C} 2 \mathrm{U}$ were limited to nitrogen, air and $\mathrm{CO}_{2}$. Alicat mass flow controllers provided an accuracy calculated by $\pm(0.8 \%$ Reading $+0.1 \%$ Full Scale (FS)), repeatability of $\pm 0.2 \% \mathrm{FS}$, response time of $<10 \mathrm{~ms}$ to setpoint changes and valve control time of less than $100 \mathrm{~ms}$. The built in actuator Proportional-Derivative (PD) controller controls actual gas flows within $\pm 1 \%$ of the setpoint.

Twenty-one Rosemount differential pressure transmitters with ranges of 0-6.9 to 0-186 kPa and an accuracy of $\pm 0.075 \%$ FS were installed in the C2U facility. Two were configured for the absolute pressure measurements at the bottom of the adsorber and the regenerator relative to ambient barometric pressure, the rest measured differential pressures across various locations in the process unit. Local barometric pressure was determined using a Mensor pressure transducer.

Five dual headed type $\mathrm{K}$ thermocouples were inserted at the location of the $\mathrm{C} 2 \mathrm{U}$ where temperature measurement was the most critical and fifteen single headed thermocouples were used for additional temperature information. All thermocouples were grounded to protect data acquisition (DAQ) card from static discharge. Two heat flux sensors (thermopiles) were attached to the wall of the regenerator to evaluate heat losses during sorbent regeneration. 
A combination of $\mathrm{N}_{2}$ and $\mathrm{CO}_{2}$ was humidified before feeding into the absorber plenum. Humidification was provided by a Controlled Evaporation Mixture (CEM) system which maintained a $2 \%$ by vol. moisture content to avoid degradation of the amine based sorbent. Water was drawn from a pressurized tank and measured by a liquid flow meter where it was mixed with the incoming gas and fed into a heated evaporator section controlled at $88^{\circ} \mathrm{C}$.

$\mathrm{CO}_{2}$ and $\mathrm{H}_{2} \mathrm{O}$ exit concentrations in both the adsorber and regenerator exit streams were monitored using PP Systems WMA-4 $\mathrm{CO}_{2}$ analyzers (range - $0-10,000$ ppm $\mathrm{CO}_{2}, 0-1000 \mathrm{mb} \mathrm{H}_{2} \mathrm{O}$ ). $\mathrm{O}_{2}$ and high $\mathrm{CO}_{2}$ concentration measurements were made with Quantek model 902P analyzers (range $0-100 \% \mathrm{O}_{2}, 0-$ $100 \% \mathrm{CO}_{2}$, accuracy $\left.1 \% \mathrm{FS}\right)$.

The regenerator bed was heated using custom made heat exchanger coils installed within the regenerator bed. A heat exchange fluid, mineral oil, was pumped through a Chromalox electric heater controlled at a target temperature and then through the heat exchange coils. The process temperatures in the middle of the regenerator were used to control the heat input to the electric heaters using a cascaded proportional/integral (PI) controller. Controlling the temperature of the regenerator bed proved more difficult than controlling the oil temperature because there were additional disturbances such as variable gas and solids flow rates, solids temperature, and heat consumption during $\mathrm{CO}_{2}$ regeneration. Cascaded PI controllers were used to compensate for these disturbances. The bed temperature was chosen as primary control variable and the oil temperature was the secondary variable. The primary loop sends the operator input set-point to the secondary loop (typically $125^{\circ} \mathrm{C}$ ). Accordingly, the PI controller adjusts the current to maintain the required oil temperature. The bed temperature can be controlled within $5 \%$ of the set-point.

The initial design for the cooling exchange coil called for installation in the adsorber because of the high amount of energy released when the bentonite material was to be employed (nominal $1.28 \mathrm{~kW}$ ). With the change to the silica based sorbents, energy production within the adsorber was greatly reduced (nominal $0.18 \mathrm{~kW}$ ), therefore, the need to remove heat within the adsorber was lessened. The cooling coils were moved to the lower loopseal to only cool the sorbent exiting the regenerator prior to reentry into the adsorber. Cooling was accomplished by passing chilled water through the heat transfer tubes. Water was cooled using a Lytron chiller Model RC045J03BG.

\subsection{Data acquisition}

Data acquisition was performed using National Instruments (NI) LabVIEW software and NI DAQ modules contained in an 8 Channel NI Compact DAQ Chassis. Two analog input cards acquired signals 
from pressure transmitters and $\mathrm{CO}_{2}$ analyzers, three temperature DAQ cards acquiring both thermocouple and heat flux sensor readings. A single Analog Output card transmitted 4-20 mA current to the solid state relay (SSR) for heater temperature control and a Digital Output card controlled the on/off state of the heater and pump relays and the solenoid valves, Also, two 4 Channel NI RS232 - ENET modules were used to communicate with the RS232 devices (flow controllers). Data regarding gas flows, temperatures, $\mathrm{CO}_{2}$ concentrations and other pertinent conditions were acquired at one second intervals throughout the duration of the experiments.

\section{Operation of Original Design}

Operation was initiated by first introducing minimal flows $\left(2 \mathrm{U}_{\mathrm{mf}}\right)$ of humidified nitrogen to the regenerator, adsorber and each loop seal. Humidification was controlled at $2 \%$ vol which is near saturation under ambient conditions. The experiments were run with a synthetic flue-gas that contained a $\mathrm{CO}_{2}$ concentration of $6-21 \%$ and a $2 \%$ by volume of moisture. The remaining was nitrogen. These experiments did not consider the effects of trace components such as $\mathrm{SO}_{2}, \mathrm{O}_{2}$ or ash.

Sorbent within the regenerator and upper loopseal was heated using the internal coils until the desired operating temperature was reached. Once this was accomplished move air was introduced and adsorber fluidization flow increased to allow solids circulation. Particles were circulated without introduction of $\mathrm{CO}_{2}$ until the desired adsorber temperature was achieved. Once thermal equilibrium was attained, move and lance flows were adjusted to yield the desired circulation rate and the required mixture of $\mathrm{N}_{2} / \mathrm{CO}_{2}$ was introduced to the adsorber. If the temperature of the solids entering the lower loopseal exceeded the desired temperature for solids entering the adsorber then cooling water flow would be pumped through the heat transfer coils in the lower loopseal. Conditions were maintained until the $\mathrm{CO}_{2}$ outlet concentrations, temperatures, circulation rate and pressures were invariant.

\subsection{Circulation rate}

Sorbent circulation rate during operation could be inferred by the pressure drop across the crossover and confirmed using the diversion valve. Previously, during operations at a given test condition the solids flow below the cyclone separator was diverted into a container for a short period of time $(15-30 \mathrm{sec})$ where approximately 100 to $200 \mathrm{~g}$ of material was extracted. The extracted material was weighed and rate of discharge was determined. Correlating these measurements with the pressure drop across the crossover yielded a method of continuous realization of circulation rate (Figure 4) for AX sorbent. Circulation rate could be varied by varying motive air (introduced two pipe diameters above the bend in the L-valve) and sparger air (which ran the length of the L-valve horizontal section). 


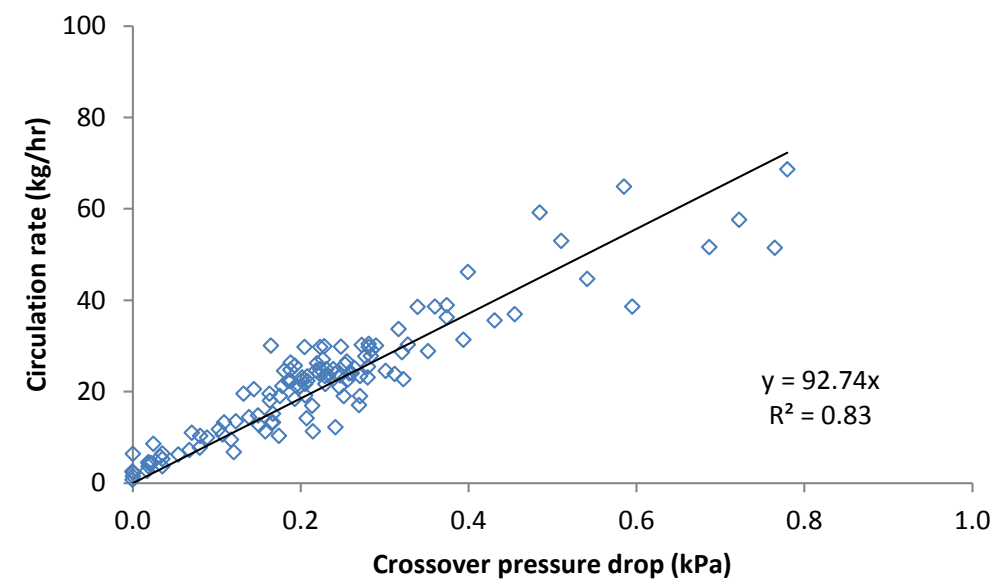

Figure 4 Correlation between sorbent circulation rate and crossover $\mathrm{dp}$.

\subsection{Sorbent and vessel material change}

The first version of the $\mathrm{C} 2 \mathrm{U}$ was transparent and constructed primarily of polycarbonate. This material was chosen because it was clear and allowed visual observation inside the system. Acrylic, while clear, could not withstand the temperatures of nearly $130^{\circ} \mathrm{C}$ anticipated in the regeneration process. The proxy sorbent (glass beads) was circulated within the $\mathrm{C} 2 \mathrm{U}$ to test hydrodynamic performance and results were as expected (Clay et al, 2013). However, the particle characteristics of the first available sorbent were different than those of the original concept. This sorbent, designated AX with properties displayed in Figure 2, had a smaller diameter, lower density and comprised of polyethylenimine (PEI) immobilized on mesoporous silica (Gray et al, 2008; Gray et al, 2005; Gray et al, 2004; Monazam et al, 2012). The minimum fluidization velocity of $\mathrm{AX}\left(\mathrm{U}_{\mathrm{mf}}=0.52 \mathrm{~cm} / \mathrm{s}\right)$ is about $20 \%$ that of glass beads, with all flows reduced accordingly. Initial testing of the AX sorbent using the $\mathrm{C} 2 \mathrm{U}$ system revealed a flaw in the materials used for construction. The amines within the sorbent reacted with the polycarbonate components causing brittle failure. The system was rebuilt using high-density polyethylene. This material, while opaque, could withstand the temperatures and amine reactions. The lengths of each reactor were maintained but the internal diameter was reduced to $0.137 \mathrm{~m}$ due to increased wall thickness. Another PEI sorbent was also tested (32D), similar to AX but with approximately half the particle density $(0.48 \mathrm{~g} / \mathrm{cc})$. 
Table 2 - Particle Properties for AX sorbent

\begin{tabular}{l|cc}
\multicolumn{1}{l}{ PROPERTY } & UNIT & AX SORBENT \\
\hline DIAMETER & $\mu \mathrm{m}$ & 115 \\
DENSITY & $\mathrm{kg} / \mathrm{m} 3$ & 910 \\
U MF $_{\text {GELDART CLASSIFICATION }}$ & $\mathrm{m} / \mathrm{s}$ & 0.0052 \\
WORKING CAPACITY & gmol CO $2 / \mathrm{kg}$ & $\mathrm{A}$ \\
\end{tabular}

The change in physical characteristics had a dramatic effect on system hydrodynamics. The sorbent behaves more as a Geldart group A material. Also, flows are greatly reduced. If the flue gas flow to the adsorber is maintained on the basis of ratio of minimum fluidization velocity $\left(6.5 \times \mathrm{U}_{\mathrm{mf}}\right)$, the new total volumetric flow to the adsorber is now 30 slpm with a $\mathrm{CO}_{2}$ flow of $4.5 \mathrm{slpm}$ and a riser gas flow of 25.2 slpm. Terminal velocity has been calculated to be $0.28 \mathrm{~m} / \mathrm{s}$, whereas the riser gas velocity is only 0.21 $\mathrm{m} / \mathrm{s}$; therefore the flow is now insufficient to carry the sorbent to the cyclone. There were two alternatives available to solve this dilemma: increase flue gas rate or decrease riser diameter. The riser diameter was eventually decreased to $2.54 \mathrm{~cm}$, reducing the flow area by one fourth and increasing the riser velocity to $0.83 \mathrm{~m} / \mathrm{s}$ (in this case), well above terminal velocity.

Assuming a comparable working capacity, $1.5 \mathrm{gmol} \mathrm{CO} / \mathrm{kg}$ sorbent and $\mathrm{CO}_{2}$ is introduced at 0.2 $\mathrm{gmol} / \mathrm{min}$, the required solids circulation rate has been reduced to $0.13 \mathrm{~kg} / \mathrm{min}(8.0 \mathrm{~kg} / \mathrm{hr})$. AX sorbent heat of adsorption is $65.8 \mathrm{~kJ} / \mathrm{mol} \mathrm{CO}_{2}$ (Spenik et al, 2015) and therefore $0.22 \mathrm{~kW}$ of energy is continuously released during adsorption. Within the regenerator, the required heat addition has also been dramatically reduced. Sorbent specific heat was estimated at $1600 \mathrm{~J} / \mathrm{kg}-\mathrm{K}$ (Spenik et al, 2015). Assuming a $40^{\circ} \mathrm{C}$ temperature increase in the regenerator, an additional $75 \mathrm{~W}$ is required. Total heat required for regeneration purposes is now $293 \mathrm{~W}$ using AX sorbent.

\subsection{Solids inventory and residence times}

Each loopseal can be filled with AX sorbent to a height of $23 \mathrm{~cm}$ (volume $\approx 3300 \mathrm{cc}$ ), the adsorber and regenerator (short version) to $36 \mathrm{~cm}$ (volume $\approx 5200 \mathrm{cc}$ ), the L-valve contains an extra volume of 2100 cc; thus the full system holds over $19100 \mathrm{cc}$ AX sorbent. The total inventory of AX sorbent, in this case, is about $12 \mathrm{~kg}$. With a solids circulation rate of $8.0 \mathrm{~kg} / \mathrm{hr}$, a sorbent particle completes a circuit in 91 minutes. The regenerator was to contain material up to the level of the heat transfer coils which is also the level where solids enter from the upper loopseal at $0.36 \mathrm{~m}$ above the distributor plate. Using AX, the 
regenerator contained $3.28 \mathrm{~kg}$ at any given instant; therefore the residence time of a particle would be 24.7 minutes in which time the $\mathrm{CO}_{2}$ must be released. Later, to extend regeneration time, this height was increased to $0.67 \mathrm{~m}$ with the addition of a spool piece.

\subsection{Heat transfer}

During a particles residence within the regenerator sufficient energy must be imparted to it to liberate the captured $\mathrm{CO}_{2}$. Energy is supplied by heated mineral oil circulating at a rate of approximately $4.5 \mathrm{lpm}$ through copper coils immersed in the bed. Specific heat and density of the oil is $1670 \mathrm{~J} / \mathrm{kg}-\mathrm{K}$ and 830 $\mathrm{kg} / \mathrm{m}^{3}$ respectively. Normally during operation, the drop in temperature between inlet and outlet oil temperatures of approximately $3^{\circ} \mathrm{C}$ was seen, indicating a heat transfer rate between the sorbent bed and coils of $312 \mathrm{~W}$. This energy transfer rate is sufficient to liberate $\mathrm{CO}_{2}$ and account for additional parasitic losses to the environment. Desired bed temperatures were achieved by adjusting the oil inlet temperature accordingly.

The heat transfer coefficient between the immersed coils and sorbent bed was determined using a correlation for horizontal tubes in a bubbling bed (Yang, 2003) using separate equations for laminar and turbulent regimes.

For $\rho_{\mathrm{p}} / \rho_{\mathrm{g}} * \mathrm{Re}_{\mathrm{p}}>2550$ (Turbulent regime)

$$
h_{c}=420\left(\frac{k_{g}}{D_{t}}\right)\left(\frac{\rho_{p}}{\rho_{g}} * \operatorname{Pr} * \frac{\mu_{g}^{2}}{g \rho_{p}^{2} d_{p}^{3}}\right)^{0.3} \operatorname{Re}_{D}^{0.3}
$$

and for $\rho_{\mathrm{p}} / \rho_{\mathrm{g}} * \mathrm{Re}_{\mathrm{p}}<2050$ (Laminar regime)

$$
h_{c}=0.66\left(\frac{k_{g}}{D_{t}}\right) \operatorname{Pr}^{0.3}\left(\frac{\rho_{p}(1-\epsilon)}{\rho_{g} \varepsilon}\right)^{0.44} \operatorname{Re}_{D}^{0.44}
$$

For $2050<\rho_{\mathrm{p}} / \rho_{\mathrm{g}} * \mathrm{Re}_{\mathrm{p}}<2550$ an average of the two can be used.

The void fraction $(\varepsilon)$ can be estimated using King's formula with the superficial velocity $U_{\mathrm{g}}$ in $\mathrm{m} / \mathrm{s}$ :

$$
\epsilon=\frac{U_{g}+1}{U_{g}+2}
$$

With the small diameter particles being used and the superficial velocities near minimum fluidization, the value $\mathrm{Ug}(\mathrm{in} \mathrm{m} / \mathrm{s}$ ) is a small number so the void fraction can usually be estimated at 0.5 . 
The heating coils consisted of two nested coils: the outer coil was a $6 \mathrm{~m}$ long, $1.25 \mathrm{~cm}$ OD copper tube of wound in twelve, $10.2 \mathrm{~cm}$ diameter loops, each loop separated by a large OD tube thickness. The inner coil was a $4 \mathrm{~m}$ long $0.95 \mathrm{~cm}$ OD copper tube wound in sixteen $5.1 \mathrm{~cm}$ loops, each loop separated by a small OD tube thickness. The tubes were joined at one end within the reactor. Oil flowed through the reactor wall into the larger diameter tube through a fitting and exited the wall through a fitting attached to the smaller tube. Total surface areas of the outer and inner tubes were 0.15 and $0.12 \mathrm{~m}^{2}$ respectively. Within the regenerator, the term $\left(\rho_{\mathrm{p}} / \rho_{\mathrm{g}}\right) \mathrm{Re}_{\mathrm{p}}=56$ for the AX sorbent, fluidized at twice $\mathrm{U}_{\mathrm{mf}}$. Therefore, the condition was laminar and the heat transfer coefficients were calculated to be 56 and $66 \mathrm{~W} / \mathrm{m}^{2}-\mathrm{K}$ for the larger and smaller tubes respectively with a combined heat transfer of $16 \mathrm{~W} / \mathrm{K}$ given the surface area of both tubes.

It should be noted that if glass beads (proxy sorbent) were used and fluidization increased to $4.5 \mathrm{x} \mathrm{U}_{\mathrm{mf}}$, then $\left(\rho_{\mathrm{p}} / \rho_{\mathrm{g}}\right) \operatorname{Re}_{\mathrm{p}}=2761$ well within the turbulent regime. The heat transfer coefficients become 905 and $529 \mathrm{~W} / \mathrm{m}^{2}-\mathrm{K}$ for the large and small diameter coils respectively and the combined heat transfer would be $203 \mathrm{~W} / \mathrm{K}$. In the original design it was shown that at least $2.0 \mathrm{~kW}$ would have been required for regeneration but this could have been supplied via the increased heat transfer.

The thermal potential required to transfer the $0.25 \mathrm{~kW}$ of heat required for regeneration is determined from $\Delta \mathrm{T}=\mathrm{Q} / \mathrm{hA}$ where $\mathrm{hA}$ is the combined heat transfer $(16 \mathrm{~W} / \mathrm{K})$, in the $\mathrm{AX}$ case $\Delta \mathrm{T}=15.4 \mathrm{~K}$. This value is used as the log mean temperature difference (LMTD) if the coils and bed can be considered as a parallel flow heat exchanger where $\mathrm{T}_{\mathrm{h}, \mathrm{i}}$ and $\mathrm{T}_{\mathrm{h}, \mathrm{o}}$ are the oil inlet and outlet temperatures and $\mathrm{T}_{\mathrm{c}, \mathrm{i}}$ and $\mathrm{T}_{\mathrm{c}, \mathrm{o}}$ are the sorbent inlet and outlet temperatures.

$$
\Delta T=L M T D=\frac{\left(T_{h, i}-T_{c, i}\right)-\left(T_{h, o}-T_{c, o}\right)}{\ln \left[\left(T_{h, i}-T_{c, i}\right) /\left(T_{h, o}-T_{c, o}\right)\right]}
$$

Previously, it was determined that the difference between inlet and outlet oil temperatures would be limited to about $3^{\circ} \mathrm{C}$. However, the sorbent temperature will vary about $30^{\circ}$. Therefore, the average of the inlet and outlet oil temperatures can be considered as single value, an approximation of the tube surface temperature $\left(\mathrm{T}_{\mathrm{s}}\right)$. Assuming the sorbent enters at $80^{\circ} \mathrm{C}$ and exits at $110^{\circ} \mathrm{C}$ the average surface temperature required is $115^{\circ} \mathrm{C}$. This is an achievable temperature that should not damage the sorbent with direct contact. The inlet oil temperature would be set to about $118^{\circ} \mathrm{C}$. In the bentonite case, the required surface temperature would be lower $\left(112^{\circ} \mathrm{C}\right)$ due to the enhanced heat transfer.

$$
T_{S}=\frac{T_{c, i}-T_{c, o} * \exp \left[\frac{\left(T_{c, o}-T_{c, i}\right)}{L M T D}\right]}{1-\exp \left[\frac{\left(T_{c, o}-T_{c, i}\right)}{L M T D}\right]}
$$




\subsection{System Development}

\subsection{The Modifications}

The C2U configuration was altered a number of times to obtain a controllable circulating system capable of operating on the Geldart group A material rather than the original Geldart group B material. The sorbent properties for the group A material where previously shown in Table 2. The original configuration, designated Mod 0, is depicted in Figure 1 where the underflow tube below the regenerator transitioned into the L-valve. The adsorber consisted of a $45 \mathrm{~cm}$ tall fluidized bed section situated below a conical transition. The transition reduced the $14 \mathrm{~cm}$ diameter adsorber to a $5 \mathrm{~cm}$ diameter riser. The regenerator underflow was relatively short so the lower loopseal (chiller) was mounted about $30 \mathrm{~cm}$ above the adsorber. Stable fully integrated operations were successful using glass beads (Clay et al, 2013); however, sorbent AX did not develop sufficient head pressure to avoid backflow of gases from the adsorber into the regenerator or allow controlled solids circulation.

In the first modification implemented for the $\mathrm{C} 2 \mathrm{U}$, Mod 1, the regenerator and upper loopseal were raised and the lower loopseal was dropped, placing its distributor plate at the same elevation as that of the adsorber. This provided the additional height needed for solids circulation and avoid gas back-flow into the regenerator from the adsorber. In the same modification, the L-valve was also replaced with a sweeping arc stand leg. Unfortunately, the aeration motive air in the sweeping arc configuration was limited to a single location near the loopseal end of the sweep. Varying the motive air introduced at this point did not allow control of circulation rate. This can be seen in Figure 5 as well as the results from Mod-2. For example, Figure 5a. indicates that for Mod-1 with a motive air flow of 6 slpm the circulation rate varied between 2 and $38 \mathrm{~kg} / \mathrm{hr}$. Experiments were conducted with motive air rates of 12 and $18 \mathrm{splm}$ with no improvement of the stability. Furthermore, there was a remarkable lack of $\mathrm{CO}_{2}$ capture, less than $30 \%$ of the $\mathrm{CO}_{2}$ introduced. In several cases the transitions between operating conditions lead to process instabilities such that the shifting in solids inventories from adsorber to regenerator led to pressure imbalances, stoppage in solids flows, and flow reversal. 

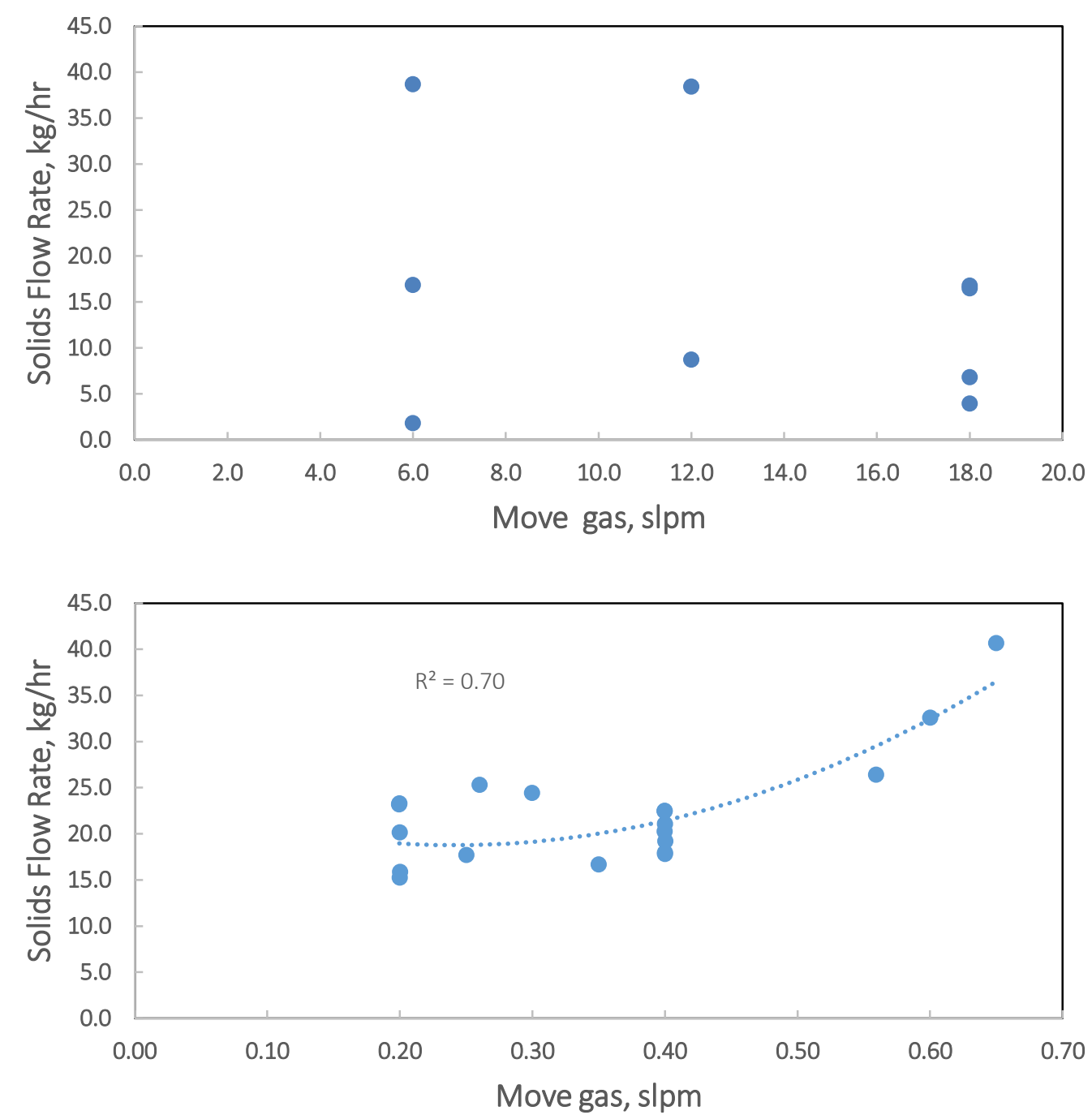

\section{Figure 5 Variations in the solids circulation rate for configuration with the long radius elbow (Mod-1) and the L-valve (Mod-2).}

As a result of these instabilities (inventory swings between vessels) and the lack of solids flow control a second set of modifications (Mod 2) were performed. The long radius elbow below the regenerator was replaced with a more conventional L-valve which consisted of vertical and horizontal piping of $4.9 \mathrm{~cm}$ inner diameter located below the regenerator. A $6.35 \mathrm{~mm}$ outer diameter stainless steel lance was inserted along the bottom of the horizontal section running from the far wall of the underflow pipe to the entrance of the loopseal chiller as is normal for L-Valves with small height to length ratios. This change allowed greater control of the circulation rate as seen in Figure $5 \mathrm{~b}$. For example, at a move gas flow rate of 0.2 slpm, the solids flow rate was $20 \pm 5 \mathrm{~kg} / \mathrm{hr}$. This was a significant improvement that allowed the research to move forward in developing an operating test unit. Even though repeatability was observed with the 
solids flow rate, other process instabilities continued to plague operations with pressure imbalances. It was observed that solids would deplete from the regenerator and accumulate in the adsorber indicating insufficient riser gas velocity.

In order to reduce the buildup of solids in the adsorber, a third modification was implemented (Mod 3) where the riser diameter was reduced from 5 to $2.5 \mathrm{~cm}$ to increase riser gas velocity with identical adsorber volumetric gas flow. The $2.54 \mathrm{~cm}$ ID riser tube was extended further down into the adsorber reactor such that the solids entered this transport line $35.6 \mathrm{~cm}$ above the gas distributor. The reduced pressure at the base of the adsorber provided a smaller hurdle for the regenerator $\Delta p$ to aid in solids transport to the adsorber. A second advantage was that the shorter height in the adsorber fluid bed altered the relative volumes of the regenerator and adsorber. The volume in fluid bed portion of the adsorber was reduced from 6.88 to $5.20 \mathrm{~L}$, while the regenerator had only $4.43 \mathrm{~L}$ reactor volume in the bed below the solids inlet port and with heat transfer surface. The volume ratio, or residence time ratio, was reduced from 1.55 to 1.15 ( $\left.V_{\text {ads }} / V_{\text {reg }}\right)$. Additionally, a heat exchange surface was added to the upper loopseal making this vessel a regenerator preheater (Mod-4). These modifications did not substantially aid in the ability to control circulation rate but there was a significant improvement in sorbent working capacity and $\mathrm{CO}_{2}$ capture efficiency. Previous experiments indicated a capture efficiency of less than $30 \%$ however subsequent tests yielded efficiencies between $70-96 \%$. Adsorption efficiency is a ratio of the amount of $\mathrm{CO}_{2}$ adsorbed to the total $\mathrm{CO}_{2}$ inputted. Regeneration efficiency is the ratio of $\mathrm{CO}_{2}$ regenerated to the amount of $\mathrm{CO}_{2}$ previously adsorbed. Regeneration efficiency can also be thought of as closure, an indication of $\mathrm{CO}_{2}$ accumulation within the sorbent over repeated cycles.

A final modification (Mod 5) was incorporated in which the regenerator was extended by approximately $0.3 \mathrm{~m}$ by the addition of a spool piece between the existing regenerator and plenum. The coils within the regenerator were also lengthened by this amount.

\subsection{Modified System Operation}

Table 3 lists parameters from a series of tests in the Mod 4 configuration that were conducted in which some variables where held nearly constant: total adsorber bed flow $\left(\sim 10.9 \pm 0.4 \mathrm{U}_{\mathrm{g}} / \mathrm{U}_{\mathrm{mf}}\right)$, regeneration temperature $\left(\sim 117 \pm 4{ }^{\circ} \mathrm{C}\right)$, adsorption temperature $\left(\sim 72 \pm 5^{\circ} \mathrm{C}\right)$, and humidification $\left(1.8 \pm 0.01 \% \mathrm{H}_{2} \mathrm{O}\right.$ vol.). Controlled variables were adsorber $\mathrm{CO}_{2}$ concentration $(6-21 \%)$ and regenerator sweep gas flow $\left(1.3-7.9 \mathrm{U}_{\mathrm{g}} / \mathrm{U}_{\mathrm{mf}}\right)$. Control of circulation rate was attempted initially with mixed results therefore motive and sparger flows were set to a minimum $(\sim 0.6 \pm 0.2 \mathrm{slpm})$ letting the circulation rate depend on adsorber flow. Difficulties maintaining a consistent circulation rate was encountered for some points within this matrix. REG 5 was the extreme case of variable circulation (Figure 6). During this test, 8.0 slpm $\mathrm{CO}_{2}$ 
was introduced to the adsorber plenum with a concentration of $16.6 \%$ where most was adsorbed while circulation was maintained. However, at approximately 1800 seconds, solids circulation abruptly ceased causing adsorption to cease some 200 seconds later but regeneration continued unabated. When circulation could be resumed then adsorption commenced almost immediately. During the period between 500 and 1500 seconds while solids were circulating at about $75 \mathrm{~kg} / \mathrm{hr}$, the adsorption efficiency was $87 \%$ of the $9.0 \mathrm{slpm}$ inputted but the regeneration efficiency was merely $50 \%$ of the $7.8 \mathrm{slpm} \mathrm{CO}_{2}$ adsorbed. Later, when circulation ceased adsorption rate declined however, regeneration continued. This can be contrasted with case REG8a (Figure 7) where circulation was maintained at a constant rate of approximately $25 \mathrm{~kg} / \mathrm{hr}$ and $93.3 \%$ of the 6 slpm $\mathrm{CO}_{2}$ inputted was adsorbed and 89.5 of that was regenerated.

Table 3 Circulating carrier tests conducted with Mod 4 configuration

\begin{tabular}{|c|c|c|c|c|c|c|c|c|c|}
\hline & & \multicolumn{3}{|c|}{ CIRCULATION } & \multicolumn{2}{|c|}{ SET POINTS } & \multicolumn{3}{|c|}{ DEPENDENT VARIABLES } \\
\hline & $\begin{array}{c}\text { Duration } \\
\text { (sec.) }\end{array}$ & $\begin{array}{l}\text { Average } \\
\text { (kg/hr.) }\end{array}$ & $\begin{array}{c}\text { stdev } \\
(\mathrm{kg} / \mathrm{hr} .)\end{array}$ & stdev/avg. & $\begin{array}{c}\mathrm{CO}_{2} \text { in } \\
(\%)\end{array}$ & $\begin{array}{c}\text { Reg Flow } \\
\left(\mathrm{U} / \mathrm{U}_{\mathrm{mf}}\right)\end{array}$ & $\begin{array}{c}\text { Ads. Eff } \\
(\%)\end{array}$ & $\begin{array}{c}\text { Reg. Eff } \\
(\%)\end{array}$ & $\begin{array}{r}\text { Capacity } \\
\text { (gmol/kg) }\end{array}$ \\
\hline REG 2A & 2640 & 25.22 & 3.49 & 0.14 & 5.9 & 1.3 & 86.0 & 53.5 & 0.26 \\
\hline REG 3 & 4920 & 28.00 & 5.35 & 0.19 & 5.9 & 3.5 & 89.9 & 90.3 & 0.27 \\
\hline REG 4 & 3600 & 20.87 & 6.67 & 0.32 & 11.9 & 3.5 & 86.2 & 67.9 & 0.68 \\
\hline REG 5 & 5760 & 33.88 & 20.08 & 0.59 & 16.6 & 3.5 & 65.1 & 73.6 & 0.54 \\
\hline REG 6 & 3600 & 17.26 & 1.47 & 0.09 & 11.8 & 3.5 & 88.6 & 78.4 & 0.82 \\
\hline REG 7 & 5400 & 16.32 & 1.04 & 0.06 & 11.8 & 6.8 & 91.5 & 86.9 & 0.88 \\
\hline REG 8 & 2700 & 22.38 & 1.24 & 0.06 & 11.8 & 5.2 & 96.4 & 77.2 & 0.70 \\
\hline REG 8A & 21120 & 24.67 & 2.29 & 0.09 & 11.8 & 5.2 & 93.3 & 89.5 & 0.59 \\
\hline REG 9 & 14400 & 25.19 & 1.85 & 0.07 & 11.8 & 5.2 & 93.0 & 83.0 & 0.59 \\
\hline REG 10 & 3600 & 27.76 & 3.38 & 0.12 & 14.7 & 3.5 & 82.4 & 76.4 & 0.60 \\
\hline REG 11 & 1740 & 33.44 & 8.42 & 0.25 & 14.5 & 3.5 & 56.9 & 73.0 & 0.47 \\
\hline REG 12 & 1200 & 52.49 & 9.63 & 0.18 & 17.5 & 3.5 & 51.1 & 52.6 & 0.34 \\
\hline REG 13 & 3540 & 48.02 & 6.56 & 0.14 & 14.7 & 4.6 & 80.8 & 81.3 & 0.37 \\
\hline REG 13A & 2700 & 35.20 & 2.78 & 0.08 & 15.6 & 4.6 & 85.6 & 76.3 & 0.48 \\
\hline REG 14 & 3600 & 21.12 & 1.70 & 0.08 & 15.8 & 7.9 & 85.1 & 100.6 & 0.87 \\
\hline REG 15 & 4500 & 22.95 & 8.19 & 0.36 & 15.8 & 1.3 & 70.0 & 76.8 & 0.64 \\
\hline REG 16 & 3600 & 20.24 & 1.63 & 0.08 & 15.7 & 4.6 & 83.1 & 94.5 & 0.86 \\
\hline REG 17 & 2700 & 22.33 & 1.89 & 0.08 & 15.8 & 4.6 & 85.9 & 89.8 & 0.75 \\
\hline REG 18 & 3600 & 23.46 & 3.38 & 0.14 & 10.5 & 4.6 & 99.0 & 100.2 & 0.54 \\
\hline REG 19 & 3600 & 24.29 & 3.26 & 0.13 & 21.0 & 4.6 & 81.6 & 72.5 & 1.04 \\
\hline REG 20 & 2700 & 17.05 & 4.96 & 0.29 & 15.8 & 4.6 & 58.4 & 73.5 & 0.64 \\
\hline
\end{tabular}




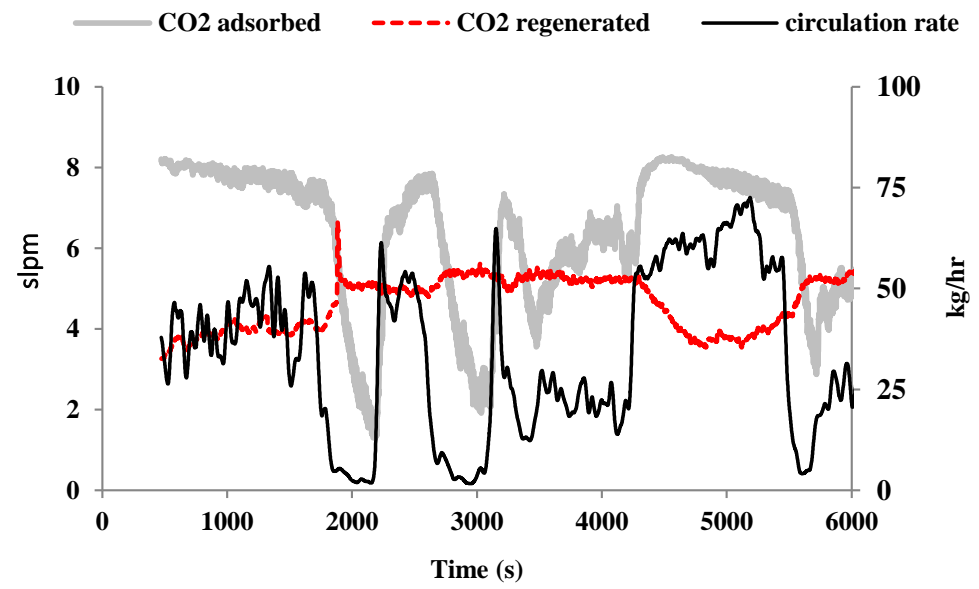

Figure 6 Time series data during continuous operations of test REG5.

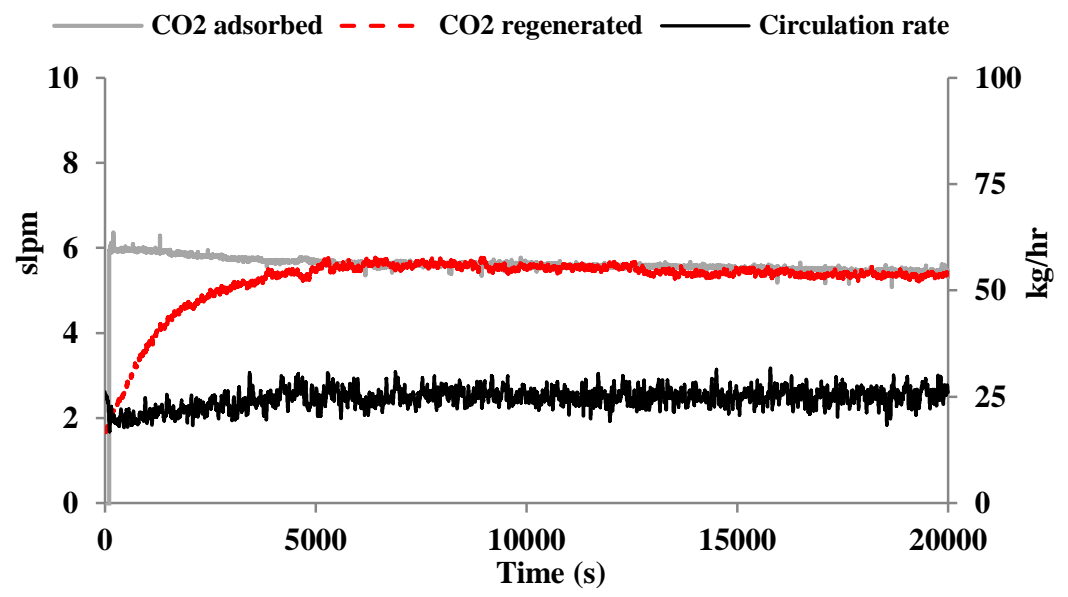

Figure 7 Time series data during continuous operations of test REG8a.

Table 4 lists parameters from a series of tests in the Mod 5 configuration which approximate those of the Mod 4 tests: total adsorber bed flow $\left(\sim 11.0 \pm 0.1 \mathrm{U}_{\mathrm{g}} / \mathrm{U}_{\mathrm{mf}}\right)$, regeneration temperature $\left(\sim 114 \pm 3^{\circ} \mathrm{C}\right)$, adsorption temperature $\left(\sim 70 \pm 5^{\circ} \mathrm{C}\right)$, and humidification $\left(1.7 \pm 0.01 \% \mathrm{H}_{2} \mathrm{O}\right.$ vol.). Controlled variables were adsorber $\mathrm{CO}_{2}$ concentration $(6-18 \%)$, regenerator sweep gas flow $\left(2.0-5.9 \mathrm{U}_{\mathrm{g}} / \mathrm{U}_{\mathrm{mf}}\right)$ and motive and sparger flows $(\sim 1.0 \pm 0.2 \mathrm{slpm})$. It should be noted that the values for the capacity in Table 4 are less than the reported working capacity in Table 1 of $1.5 \mathrm{~mol} / \mathrm{kg}$. The value in Table 1 is for "clean" or "fresh" sorbent. The values in Table 4 are less than this amount, ranging from a low of $0.34 \mathrm{~mol} / \mathrm{kg}$ to a high of $1.36 \mathrm{~mol} / \mathrm{kg}$. In an earlier publication on the performance of this sorbent in batch tests, Spenik et al. (2015) point to overheating as a reason why the capacity might be lower than the theoretical value for a "fresh" sorbent. The main point made in that discussion was that the heating coils were at an elevated 
temperature and that slow moving sorbent particles that were in direct contact with the heating coils were overheated, causing thermal degradation of the sorbent.

A second reason why sorbent capacity is lower in than the theoretical value is that the sorbent is not being fully regenerated back to a value of zero. It has residual $\mathrm{CO}_{2}$ on it at or near the equilibrium value associated with the regenerator temperature and $\mathrm{CO}_{2}$ content in the gas. In this regard, the sorbent performance cycles between the regenerator near equilibrium value (i. e.: lean or low loading) and fully carbonated (i.e.: high loading). For example, if the residual CO2 on the sorbent is $0.5 \mathrm{~mole} / \mathrm{kg}$, the working capacity is reduced from $1.5 \mathrm{~mole} / \mathrm{kg}$ to $1.0 \mathrm{~mole} / \mathrm{kg}$.

The Mod 4 modification increased the adsorption efficiency to nearly $100 \%$ for $\mathrm{CO}_{2}$ concentrations around $6 \%$ but the efficiency decreased with increasing $\mathrm{CO}_{2}$ concentration (Figure 8). The subsequent Mod 5 redesign to increase the regenerator residence time provided nearly $100 \%$ regeneration independent of circulation rate fluctuations as is shown in Figure 9.

Table 4 Circulating carrier tests conducted with Mod 5 configuration

CIRCULATION

SET POINTS

\begin{tabular}{|c|c|c|c|c|c|c|c|c|c|}
\hline & $\begin{array}{c}\text { Duration } \\
\text { (sec.) }\end{array}$ & $\begin{array}{c}\text { Average } \\
\text { (kg/hr.) }\end{array}$ & $\begin{array}{c}\text { stdev } \\
(\mathrm{kg} / \mathrm{hr} .)\end{array}$ & stdev/avg. & $\begin{array}{c}\mathrm{CO}_{2} \text { in } \\
(\%)\end{array}$ & $\begin{array}{c}\text { Reg Flow } \\
\left(\mathrm{U} / \mathrm{U}_{\mathrm{mf}}\right)\end{array}$ & $\begin{array}{c}\text { Ads. Eff } \\
(\%)\end{array}$ & $\begin{array}{c}\text { Reg. Eff } \\
(\%)\end{array}$ & $\begin{array}{r}\text { Capacity } \\
\text { (gmol/kg) }\end{array}$ \\
\hline AX 2 & 3306 & 15.4 & 1.15 & 0.07 & 12.3 & 2.2 & 78.7 & 103.6 & 0.82 \\
\hline AX 4 & 7993 & 20.9 & 5.48 & 0.26 & 12.3 & 2.1 & 67.0 & 85.0 & 0.51 \\
\hline AX 5 & 4993 & 8.7 & 2.71 & 0.31 & 12.2 & 2.6 & 58.6 & 99.2 & 1.36 \\
\hline AX 6 & 7992 & 14.1 & 3.38 & 0.24 & 12.0 & 3.3 & 70.6 & 100.1 & 0.67 \\
\hline AX 7 & 7093 & 15.4 & 0.88 & 0.06 & 6.0 & 2.2 & 96.4 & 100.8 & 0.45 \\
\hline AX 8 & 5991 & 16.9 & 2.17 & 0.13 & 18.0 & 2.2 & 55.8 & 102.5 & 0.73 \\
\hline AX 9 & 8548 & 14.4 & 7.24 & 0.50 & 11.9 & 2.8 & 78.6 & 97.0 & 1.03 \\
\hline AX 9B & 6242 & 15.6 & 3.22 & 0.21 & 12.0 & 2.4 & 70.4 & 100.0 & 0.68 \\
\hline AX 10 & 1441 & 15.0 & 0.92 & 0.06 & 12.0 & 2.0 & 71.5 & 90.8 & 0.46 \\
\hline AX 11 & 4200 & 15.7 & 1.90 & 0.12 & 11.9 & 3.9 & 72.4 & 91.4 & 0.65 \\
\hline AX 12 & 7999 & 15.3 & 1.98 & 0.13 & 12.0 & 3.5 & 79.5 & 99.0 & 0.67 \\
\hline AX 13 & 3000 & 16.2 & 3.97 & 0.24 & 12.0 & 4.5 & 68.1 & 98.2 & 0.92 \\
\hline AX 14 & 4992 & 17.7 & 3.82 & 0.22 & 12.1 & 5.4 & 80.7 & 92.9 & 0.61 \\
\hline AX 15 & 5992 & 9.6 & 1.19 & 0.12 & 6.0 & 4.0 & 96.4 & 102.0 & 0.82 \\
\hline AX 16 & 2992 & 15.0 & 2.21 & 0.15 & 18.0 & 5.1 & 50.4 & 93.5 & 0.82 \\
\hline AX 17 & 6000 & 18.9 & 4.09 & 0.22 & 12.1 & 3.4 & 77.0 & 96.6 & 0.60 \\
\hline AX 18 & 9992 & 16.4 & 6.09 & 0.37 & 12.0 & 2.4 & 59.1 & 100.8 & 0.62 \\
\hline AX 20 & 7898 & 22.1 & 1.05 & 0.05 & 5.9 & 4.2 & 98.5 & 99.8 & 0.34 \\
\hline $\mathbf{A X} 21$ & 10999 & 13.1 & 1.44 & 0.11 & 6.0 & 5.9 & 98.5 & 100.5 & 0.52 \\
\hline AX 22 & 7150 & 16.3 & 1.09 & 0.07 & 5.9 & 2.9 & 98.5 & 105.0 & 0.48 \\
\hline
\end{tabular}




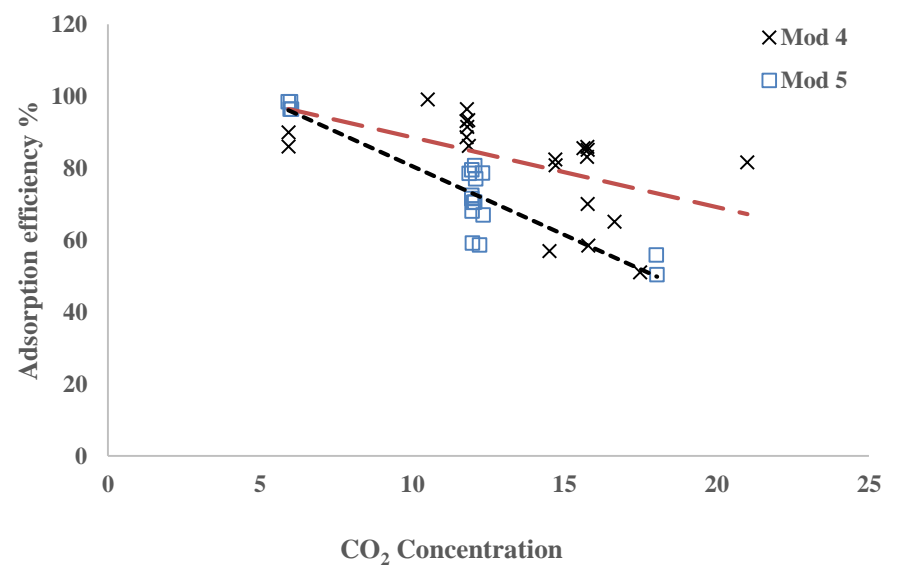

Figure 8 Adsorption efficiencies in the Mod 4 and Mod 5 configurations

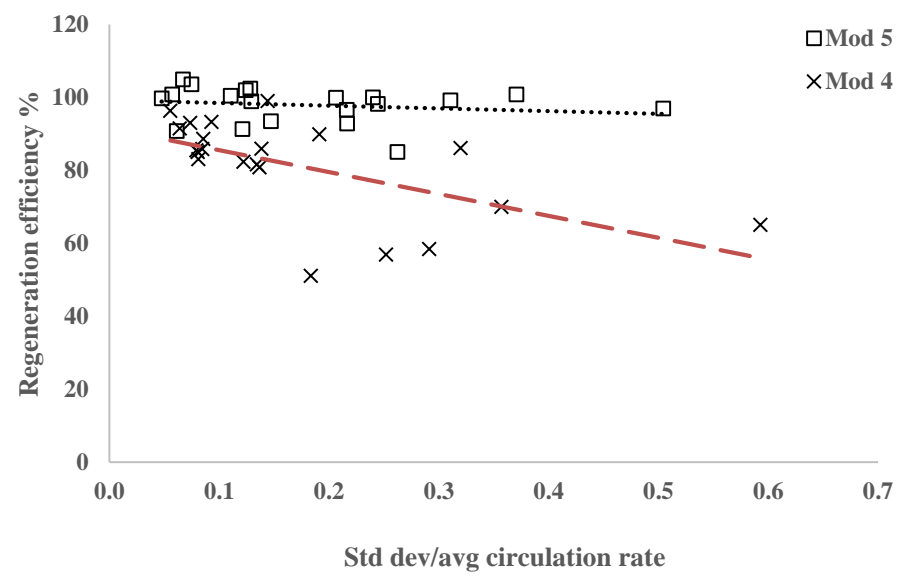

Figure 9 Regeneration efficiencies in the Mod 4 and Mod 5 configurations

\section{Summary:}

Significant $\mathrm{CO}_{2}$ capture was demonstrated in a relatively simple, continuous fluidized bed processes. The adsorption of carbon dioxide $\left(\mathrm{CO}_{2}\right)$ by immobilized amine (PEI) on mesoporous silica was investigated using a series of coupled fluidized beds referred to as the $\mathrm{C} 2 \mathrm{U}$. This test unit employed fluidized bed technology to adsorb $\mathrm{CO}_{2}$ from a simulated mixture of gases representing the flue gas from a pulverized coal power plant. The sorbent was then transferred using non-mechanical valve technology (upper loop seal) into a fluidized bed where it was regenerated by heating it to $120^{\circ} \mathrm{C}$ under a nitrogen flow where the solids moved down counter to the up flowing sweep gas. The nitrogen and $\mathrm{CO}_{2}$ gas stream was then 
released to the atmosphere. In a commercial system, steam would have been used for fluidization, the escaping gas would have been captured, the steam condensed and the remaining $\mathrm{CO}_{2}$ would then be compressed to be utilized or sequestered. In depth characterization of amine-based sorbents enabled identification of the critical parameters necessary to demonstrate these performance advancements. Tests were completed to evaluate the optimum reactor throughput and maximum working capacity. Several additional reactor modifications have been identified which are expected to improve performance significantly. As a means to summarize the modification steps, Table 5 below outlines the changes made and the impact observed.

Table 5: Advancements made and problems solved through each stage of modification.

\begin{tabular}{|c|c|c|c|}
\hline No. & Description of changes & Basis/Constraints & Performance/Effect of Modifications \\
\hline Mod 0 & $\begin{array}{l}\text { Baseline design for Group B } \\
\text { Material }\end{array}$ & $\begin{array}{l}\text { Height of facility, and gas } \\
\text { throughput defined. } \\
\text { Transparent for visual } \\
\text { observation. }\end{array}$ & $\begin{array}{l}\text { Operated well in cold flow tests well on } \\
\text { glass beads, but did not circulate reliably } \\
\text { with sorbent. Gas flow reversal was } \\
\text { observed. Acrylic vessels corroded, } \\
\text { embrittled, and lost integrity upon } \\
\text { exposure to PEI loaded sorbent. }\end{array}$ \\
\hline Mod1 & $\begin{array}{l}\text { Replace acrylic with } \\
\text { polyethylene vessels and } \\
\text { reinforced rubber connecting } \\
\text { tubes. Increase overall height } \\
\text { in recycle leg (standleg below } \\
\text { regenerator) by dropping the } \\
\text { lower loopseal and raising the } \\
\text { upper loopseal and } \\
\text { regenerator. Replace L-valve } \\
\text { at base of standleg with a } \\
\text { sweeping arc. }\end{array}$ & $\begin{array}{l}\text { Loss ability to visually observe } \\
\text { performance. Reduced the } \\
\text { height between cyclone and } \\
\text { loopseal. Increased wall } \\
\text { thickness and reduced inner } \\
\text { diameter. }\end{array}$ & $\begin{array}{l}\text { Circulation limited to very narrow range, } \\
\text { with low solids flows and intermittent } \\
\text { stoppages. Lack of solids flow control. } \\
\text { Process upsets occasionally led to loss of } \\
\text { sorbent inventory through cyclone, } \\
\text { clogging the downstream barrier filters. }\end{array}$ \\
\hline Mod2 & $\begin{array}{l}\text { Replaced sweeping arc with } \\
\text { L-valve and sparger on } \\
\text { horizontal. }\end{array}$ & $\begin{array}{l}\text { Reduced the potential for gas } \\
\text { bypassing standpipe solids to } \\
\text { minimize pressure loss needed } \\
\text { for solids circulation and } \\
\text { reduce pressure upset events. } \\
\text { Enabled more direct control of } \\
\text { solids flow. }\end{array}$ & $\begin{array}{l}\text { Continuous circulation of solids achieved } \\
\text { with fewer upset events. Capture } \\
\text { efficiency remained low for all cases } \\
\text { below } 80 \% \text {. Solids would deplete from the } \\
\text { regenerator and accumulate in the } \\
\text { adsorber. }\end{array}$ \\
\hline Mod3 & $\begin{array}{l}\text { Reduced the riser diameter } \\
\text { from } 5 \text { to } 2.5 \mathrm{~cm} \text {. }\end{array}$ & $\begin{array}{l}\text { Reduced the back pressure of } \\
\text { the adsorber on the regenerator } \\
\text { as well as the relative volume } \\
\text { of the adsorber compared to the } \\
\text { regenerator }\end{array}$ & $\begin{array}{l}\text { Target capture efficiency achieved under } \\
\text { select conditions. Operations continue to } \\
\text { be limited to select adsorber flows but } \\
\text { circulation rates can be varied somewhat. } \\
\text { Capture efficiencies are achieved above }\end{array}$ \\
\hline
\end{tabular}




\begin{tabular}{|l|l|l|l|}
\hline Mod4 & $\begin{array}{l}\text { Provide sorbent preheat in } \\
\text { return leg upstream from } \\
\text { regenerator }\end{array}$ & $\begin{array}{l}\text { The design was to add heat } \\
\text { transfer surface to regenerator, } \\
\text { but the heat coils added to } \\
\text { loopseal (V2000) were } \\
\text { removed from the regenerator } \\
\text { because additional length } \\
\text { increased back pressure } \\
\text { pumping the heat transfer fluid } \\
\text { (oil). }\end{array}$ & Performance was consistent with Mod3. \\
\hline Mod5 & $\begin{array}{l}\text { Add additional regenerator } \\
\text { volume }\end{array}$ & $\begin{array}{l}\text { An additional 0.3 m of height } \\
\text { was added to the regenerator } \\
\text { enabling operations with larger } \\
\text { relative volume in the } \\
\text { regenerator and higher height in } \\
\text { the return leg. }\end{array}$ & $\begin{array}{l}\text { Performance was consistent with Mods 3 } \\
\text { and 4. Further analysis is required to } \\
\text { establish the effect of regenerator volume } \\
\text { and heat transfer surface on the overall } \\
\text { performance. }\end{array}$ \\
\hline
\end{tabular}

\section{Nomenclature:}

$\mathrm{A}_{\mathrm{pp}}-$ Projected particle area $\left(\mathrm{m}^{2}\right)$

$\mathrm{C}_{\mathrm{D}}-$ Drag coefficient

$\mathrm{CO}_{2} \%-\mathrm{CO}_{2}$ volume concentration in adsorber flow (\%)

$\mathrm{d}_{\mathrm{p}}-$ Particle diameter $(\mathrm{m})$

$\mathrm{D}_{\mathrm{t}}-$ Heat transfer tube diameter $(\mathrm{m})$

$F_{a}-$ Total flow to adsorber plenum (slpm)

$\mathrm{F}_{\mathrm{ls}}-$ Total flow to loopseal plenums (slpm)

$\mathrm{F}_{\mathrm{mv}}-$ Total move air flow (slpm)

$F_{r}-$ Total flow to regenerator plenum (slpm)

$\mathrm{g}$ - gravitational acceleration $\left(9.8 \mathrm{~m} / \mathrm{s}^{2}\right)$

$\mathrm{h}_{\mathrm{c}}-$ Heat transfer coefficient between immersed tube and bed $\left(\mathrm{W} / \mathrm{m}^{\left.2-{ }^{\circ} \mathrm{K}\right)}\right.$

$\mathrm{k}_{\mathrm{g}}-$ Gas conductive heat transfer coefficient $\left(\mathrm{W} / \mathrm{m}-{ }^{\circ} \mathrm{K}\right)$

LMTD - Log mean temperature difference $\left({ }^{\circ} \mathrm{K}\right)$

$\mathrm{M}_{\mathrm{inv}}-$ Sorbent mass inventory $(\mathrm{kg})$

Pr - Prandtl \# 
$\operatorname{Re}_{\mathrm{p}}-$ Reynolds' \# (particle)

$\mathrm{T}_{\mathrm{c}, \mathrm{i}}-$ Solids inlet temperature (regenerator)

$\mathrm{T}_{\mathrm{c}, \mathrm{o}}-$ Solids exit temperature (regenerator)

$\mathrm{T}_{\mathrm{h}, \mathrm{i}}-$ Oil inlet temperature (regenerator)

$\mathrm{T}_{\mathrm{h}, \mathrm{o}}-$ Oil inlet temperature (regenerator)

$\mathrm{T}_{\mathrm{s}}-$ Coil average surface temperature

$\mathrm{U}_{\mathrm{mf}}-$ Minimum fluidization velocity $(\mathrm{m} / \mathrm{s})$

$\mathrm{U}_{\mathrm{g}}-$ Superficial gas velocity $(\mathrm{m} / \mathrm{s})$

$\mathrm{V}_{\text {term }}-$ Particle terminal velocity $(\mathrm{m} / \mathrm{s})$

W - Particle weight $(\mathrm{kg})$

$\varepsilon-$ Void fraction

$\eta$-Capture efficiency (\%)

$\mu_{\text {gas }}-$ Gas viscosity ( $\left.\mathrm{kg} / \mathrm{ms}\right)$

$\rho_{\mathrm{g}}-$ Gas density $\left(\mathrm{kg} / \mathrm{m}^{3}\right)$

$\rho_{\mathrm{p}}$ - Particle density $\left(\mathrm{kg} / \mathrm{m}^{3}\right)$

\section{Disclaimer}

This project was funded by the Department of Energy, National Energy Technology Laboratory, an agency of the United States Government, through a support contract with URS Energy \& Construction, Inc. Neither the United States Government nor any agency thereof, nor any of their employees, nor URS Energy \& Construction, Inc., nor any of their employees, makes any warranty, expressed or implied, or assumes any legal liability or responsibility for the accuracy, completeness, or usefulness of any information, apparatus, product, or process disclosed, or represents that its use would not infringe privately owned rights. Reference herein to any specific commercial product, process, or service by trade name, trademark, manufacturer, or otherwise, does not necessarily constitute or imply its endorsement, recommendation, or favoring by the United States Government or any agency thereof. The views and opinions of authors expressed herein do not necessarily state or reflect those of the United States Government or any agency thereof. 


\section{Acknowledgements}

This work was funded by the U.S. Department of Energy, Office of Fossil Energy's Carbon Capture Simulation Initiative through the National Energy Technology Laboratory

\section{References}

Amines and Plasticizers Limited, 2015. MDEA Parameters. Retrieved from www.amines.com/mdea_comp.htm

Black, J., 2010. Cost and performance baseline for fossil energy plants Volume 1: bituminous coal and natural gas to electricity. DOE/NETL-2010/1397 Final Report.

Breault, R.W. , Huckaby, E. D., 2013. Parametric behavior of a CO2 capture process: CFD simulation of solid-sorbent CO2 absorption in a riser reactor. Applied Energy 112, 224-234.

Burchell, T.D., Judkins, R.R., Rogers, M.R., Williams, A.M., 1997. A novel process and material for the separation of carbon dioxide and hydrogen sulfide gas mixtures. Carbon 35, 1279-1294

Ciferno, J., 2008. $\mathrm{CO}_{2}$ Capture-Ready Coal Power Plants. DOE/NETL- 2007/1301 Final Report.

Clay, S., Spenik, J., Snyder, D., Huckaby, E.D., 2013. CO2 Absorption Loop Experiment with EulerianLagrangian Simulation. Powder Technol. 242, 100-107.

Fisher, D., Keller, G., 2011. Process analyses and R\&D plans forward for dry-sorbent-based processes for removal of $\mathrm{CO}_{2}$ from power plant flue gas, DOE/NETL-2011/1475, 38.

Frimpong, R.A., Johnson, D., Richburg, L., Hogston, B., Remias, J.E., Neathery, J.K., Liu, K.L., 2013. Compariosn of solvent performance for $\mathrm{CO} 2$ capture from coal-derived flue gas: A pilot scale study. Chem. Eng. Res. Des. 91, 963-969.

Gray, M.L., Soong, Y., Champagne, K.J. U.S. Patent 6,547,854, April 15, 2003.

Gray, M.L., Champagne, K.J., Fauth, D., Baltrus, J.P., Pennline, H., 2008. Performance of immobilized tertiary amine solid sorbents for the capture of carbon dioxide. Int. J. Greenh. Gas Control. 2, 3-8

Gray, M.L., Soong, Y., Champagne, K.J., Pennline, H., Baltrus, J.P., Jr., Khatri, R., Chuang, S.S.C., Filburn, T., 2005. Improved immobilized carbon dioxide capture sorbents. Fuel Process. Technol. 86, $1449-1455$.

Gray, M. L., Soong, Y., Champagne, K.J., Pennline, H.W., Baltrus, J., Stevens, R.W., Khatri, R., Jr., Chuang, S.S.C., 2004. Capture of carbon dioxide by solid amine sorbents. Int. J. Environ. Technol. Manage. $4(1 / 2), 82$.

Heydari-Gorji, A., Belmabkhout, Y., Sayari, A., 2011. Polyethylenimine impregnated mesoporous silica: effect of amine loading and surface alkyl chains on CO2 adsorption. Langmuir. 27, 12411-12416. 
Hoffman, J.S., Richards, G.A., Pennline, H.W., Fischer, D., Keller, G., 2008. Factors in reactor design for carbon dioxide capture with solid, regenerable sorbents. International Technical Conference on Coal Utilization \& Fuel Systems, Clearwater, FL 2008, Coal Technology Association, Gaithersburg, MD.

Monazam, E.R., Shadle, L.J., Miller, D.C., Pennline, H.W., Fauth, D.J., Hoffman, J.S., Gray, M.L., 2012. Equilibrium and kinetics analysis of carbon dioxide capture using immobilized amine on a mesoporous silica, AIChE J. 59, 923-935.

Pires, J.C.M., Martins, F.G., Alvim-Ferraz, M.C.M, Simoes, M., 2011. Recent develoments of carbon capture and storage: An overview. Chem. Eng. Res. Des. 89, 1446-1460.

Proll, T., Schony, G., Sprachmann, G., Hofbauer, H., 2016. Introduction and evaluation of a double loop staged fluidized bed system for post-combustion $\mathrm{CO}_{2}$ capture using solid sorbents in a continuous temperature swing adsorption process. Chem. Eng. Sci. 141, 166-174.

Ryan, E.M., DeCroix, D., Breault, R., Xu, W., Huckaby, E.D., Saha, K., Dartevelle, S., Sun, X., 2013. Multi-phase CFD modeling of solid sorbent carbon capture system. Powder Technology 242 117-134.

Samanta, A., Zhao, A., Shimizu, G.K.H., Sarkar, P., Gupta, R., 2012. Post-Combustion $\mathrm{CO}_{2}$ Capture Using Solid Sorbents: A Review. Ind. Eng. Chem. Res. 51, 1438-1463.

Siriwardane, R. Solid sorbents for removal of carbon dioxide from gas stream at low temperatures. U.S. Patent 6,908,497 B1, June 21, 2005.

Sjostroma, S., Krutkaa, H., Starnsa, T., Campbell, T., 2011. Pilot Test Results of Post-Combustion $\mathrm{CO}_{2}$ Capture Using Solid Sorbents, Energy Procedia. 4, 1584-1592.

Spenik, J., Shadle, L., Breaut, R., Hoffman, J., Gray, M., 2015.Cyclic tests in batch mode of $\mathrm{CO}_{2}$ adsorption and regeneration with sorbent consisting of immobilized amine on a mesoporous silica, Ind. Eng. Chem Res. 54, 5388 - 5397.

Susarla, N., Haghpanah, R., Karimi, I.A., Farooq, S., Rajendran, A., Tan, L.S.C., Lim, J.S.T., 2015. Energy and cost estimates for capturing $\mathrm{CO} 2$ from a dry flue gas using pressure/vacuum swing adsorption. Chem. Eng. Res. Des. 102, 354-367

U.S. Energy Information Administration, 2012. Annual Energy Review 2011. DOE/EIA-0384(2011).

Veneman, R., Li, Z.S., Hogendoorn, J.A., Kersten, S.R.A., Brilman, D.W.F., 2012. Continuous CO2 capture in a circulating fluidized bed using supported amine sorbents. Chem. Eng. J. 207-208, 18-26.

Yang, W.C., Hoffman, J., 2009. Exploratory Design Study on Reactor Configurations for Carbon Dioxide Capture from Conventional Power Plants Employing Regenerable Solid Sorbents, Ind. Eng. Chem. Res. 48, 341-351.

Yang, W.C., 2003. Handbook of Fluidization and Fluid Particle Systems, Marcel Dekker, Inc.

Yong, Z., Mata, V., Rodrigues, A. E., 2002. Adsorption of carbon dioxide at high temperature-a review. Sep. Purif. Technol. 26, 195-205.

Zhang, W., Liu, H., Sun, C., Drage, T.C. Snape, C.E., 2014. Capturing CO2 from ambient air using polyethyleneimine-silica adsorbent in fluidized beds. Chem. Eng. Sci. 116, 306-319. 
Zhao, W., Zhang, Z., Li, Z., Cai, N., 2013. Continuous CO2 capture in dual fluidized beds using silica supported amine. Energy Preocedia 37, 89-98.

Zhenissova, A., Micheli, F., Rossi, L., Stendardo, S., Foscolo, P.U., Gallucci, K., 2014. Experimental evaluation of $\mathrm{Mg}$ - and Ca-based synthetic sorbents for CO2 capture. Chem. Eng. Res. Des. 92, 727-740. 


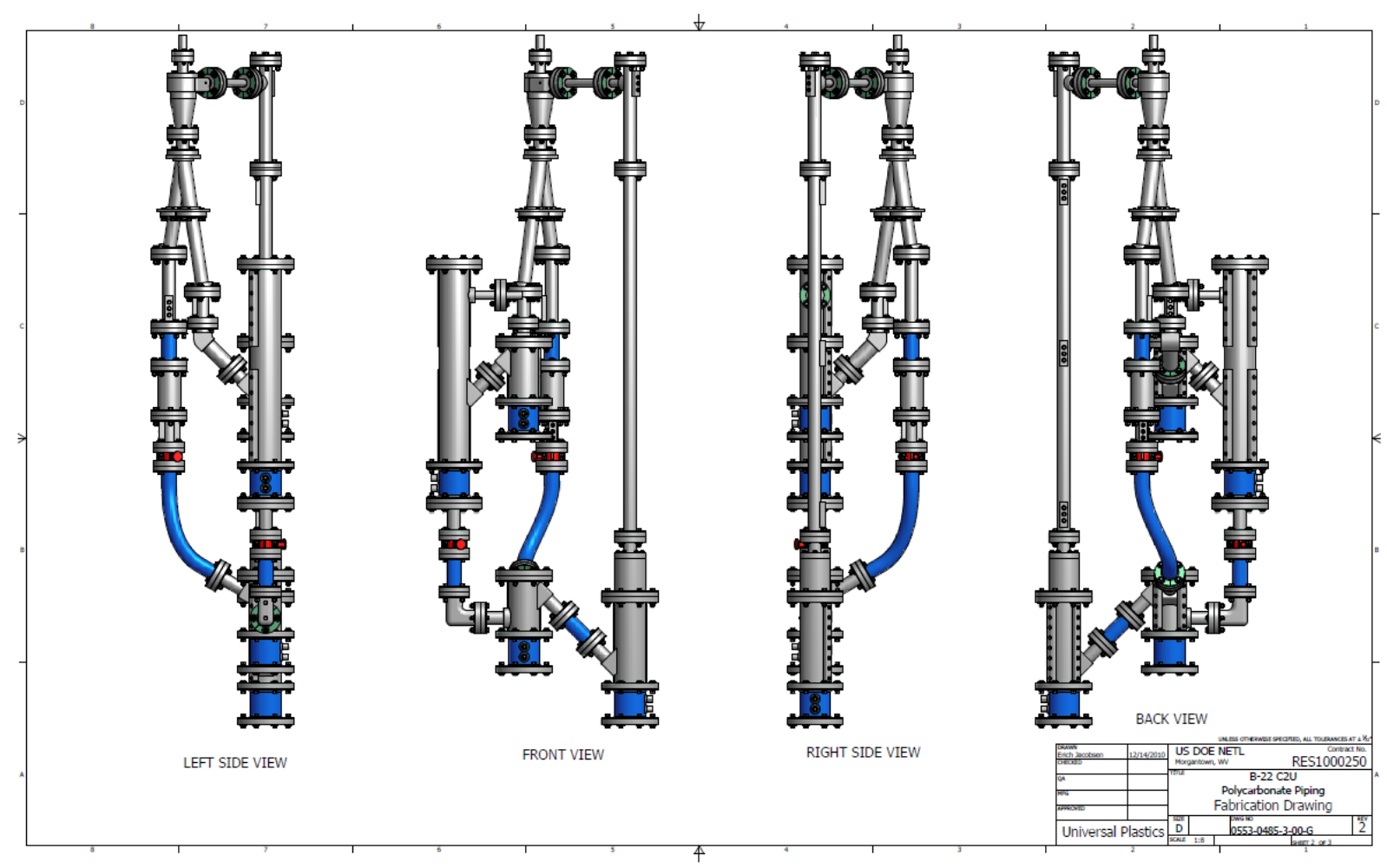

